\title{
IMPACT OF LONG-FERMENTED SOURDOUGH ON THE TECHNOLOGICAL AND PREBIOTICAL PROPERTIES OF RYE BREAD
}

\author{
Rūta Mūrniece" ${ }^{\#}$ and Dace Kḷava \\ Faculty of Food Technology, Latvia University of Life Sciences and Technologies, 2 Lielā Str., Jelgava, LV 3001, LATVIA \\ \# Coresponding author, rutapau@gmail.com
}

Communicated by Tatjana Ķince

\begin{abstract}
The technology of fermented rye bread in Latvia has a strong traditional value. Microorganisms play an important role in the fermentation process of sourdough bread, mainly due to lactic acid bacteria ( $L A B)$. Traditional rye bread in Latvia is prepared using scalded flour and sourdough. Total fermentation time can be from 6 till 48 hours, depending on the bakery. Usually sourdough contains two to five $L A B$ species. One of the metabolites in sourdough produced by $L A B$ is exopolysaccharide (EPS). It has been found that $20 \%$ of the analysed strains in sourdough are able to produce EPSs from sucrose - mainly fructans and glucans are produced. The exopolysaccharides produced by $L A B$ are able to bind water, improving the quality of bread, increasing the volume, delaying staling of the bread, and thus extending the shelf life. Many studies have shown that EPSs produced by $L A B$ can improve the growth of probiotics in the human body, thus improving the immune function. Of particular interest about possible prebiotic functions are EPSs produced by $L A B$. Long rye bread scalding fermentation technology can improve the texture, quality, and shelf life of bread, as well as functionally affect the human immune system.
\end{abstract}

Key words: scald, exopolysaccharides, microflora, lactic acid bacteria.

\section{INTRODUCTION}

Traditionally rye bread is made using scalding of flour, rye sourdough, and long fermentation time. Fermentation is one of the oldest types of product processing, and is applied in the processing of milk, cereals, vegetables, and fruits. Fermentation is part of culinary traditions and values and influences both sensory and technological improvements in the final product. With the development of science and understanding of a healthier and more functional diet, the fermentation process has been studied in depth not only for dairy products, but over the past ten years also for cereal products (Tsafrakidou et al., 2020).

To bake a rye bread, three main ingredients are needed flour, water, and leavening agent. Sourdough can be used as the leavening agent for bread in artisanal bakeries as well as in an industrial scale. Sourdough provides volume, texture, and flavour to the bread. The use of sourdough in bread making is one of the oldest biotechnological processes. Although yeast has partially replaced this use in wheat bread production, it is still needed in rye bread production where acidification is required to ensure bread quality and for inhibiting amylase (Gänzle and Zheng, 2019).

It is well established that the use of sourdough can improve the technological properties of rye bread, sensory properties, increase the nutritional value and its bioavailability, as well as provide prebiotic functions of exopolysaccharides.

\section{BIOCHEMICAL PROCESSES IN THE FERMENTA- TION OF SOURDOUGH}

Sourdough is a fermented mixture of flour and water. The fermentation is done by lactic acid bacteria (LAB) and yeasts. Sourdough fermentation can be started 1) spontaneously, by acting on the microflora present in the flour and the environment, 2) by adding already mature sourdough to the flour-water mixture, and 3) by adding starter cultures. Sourdough is maintained and propagated by mixing a portion of mature sourdough with fresh flour and water and fermented for several hours at temperature around $30{ }^{\circ} \mathrm{C}$ (Viiard et al., 2016). 
Scalded flour or scald is rye flour and hot water mixed and slowly cooled. Caraway and rye malt are usually added. During scald preparation, the amylases from malt and flour break down starch into maltodextrins, which are hydrolysed into maltose and glucose.

The fermentation time can vary widely and is influenced by the type of sourdough used, the fermentation temperature, the type of flour used and the desired results. A short fermentation time can be classified as 4-6 hours, moderate fermentation time 6-24 h, and long fermentation time 24-72 h (Viiard et al., 2016; De Vuyst et al., 2017).

Sourdough technology is used all over the world and, depending on the area, country, traditions, and the desired result, the way they are prepared and maintained can vary significantly. To summarise sourdough types, scientists have developed classifications and a specific terminology based on processing conditions and technology used.

Sourdough is classified into four types (Viiard et al., 2016; De Vuyst et al., 2017; Pćcularu-Burada et al., 2020) :

TYPE I - sourdough used for leavening, aroma, and acidification. Fermentation has taken place spontaneously from LAB and yeasts from flour and the environment. Fermentation is carried out at room temperature, which can be variable, but usually $20-30{ }^{\circ} \mathrm{C}$. The fermentation time is short to moderate $(6-24 \mathrm{~h})$. Renewal takes place with daily propagation (backslopping). Backslopping involves some part of mature sourdough mixed with fresh flour and water and fermented to obtain a new portion of sourdough.

TYPE II - sourdough used for acidification, used in largescale production, having semi-fluid consistence, long fermentation time (24-72 h), and temperature usually above $30{ }^{\circ} \mathrm{C}$. For fermentation selected LAB strains are used, commonly using a liquid starter culture. Backstopping is not required.

TYPE III - sourdough for taste and aroma enhancing. Commercial starter cultures are used for initiation, after fermentation the sourdough is dried.

TYPE IV - combination between type I and type II. Flour is fermented by a selected starter culture, and later backslopping is used for daily renewal.

Every sourdough is developed using a regeneration method called generation. The refreshment method is the main technique used to ensure the metabolic activity of microorganisms and sourdough stability. Refreshments are formed when water and flour are mixed with part of the sourdough (also called "mother sponge"), fermented to reach the intended acidity (Corsetti, 2013).

The sourdough microflora, especially as a result of spontaneous fermentation, usually consists of LAB and yeasts. Dominant LAB species in the rye and wheat sourdough are from Lactobacillus, Enterococcus, Lactococcus, Leuconostoc, Pediococcus, and Weisella genera. The dominant yeasts are from genera Candida and Saccharomyces. Sour- dough is a complex microbial ecosystem and metabolic interaction between LAB and yeast is inevitable. In the sourdough system, LAB mainly provides acidification, while yeasts provide for the formation of aroma compounds. During fermentation, the $\mathrm{pH}$ of the sourdough changes significantly, which can improve the activity of some enzymes as well as inactivate them. When the activity of enzymes changes, the availability of starch, minerals and vitamins is significantly affected (Therdthai, 2014).

LAB can be divided into three groups (Huys et al., 2013):

- obligate homofermentative bacteria (L. amylovorus, $L$. acidophilos, L. farciminis, L. mindensis, L. crispatus, L. johnsonii, and L. amylolyticus);

- obligate heterofermentative bacteria (L. acidifarinae, $L$. brevis, L. fermentum, L. reuteri, L. rossiae, L. frumenti, and L. zymae);

- facultative heterofermentive bacteria (L. plantarum, $L$. pentosus, L. casei, L. paralimentarius, and L. alimentarius).

To balance the aroma, the lactate and acetate ratio should be $4: 1$. Therefore, the combination of homofermentative (producing lactate) and heterofermentative (producing lactate and acetate) LAB will give a fuller aroma. The heterofermentative lactic acid bacterium produces both lactic acid and acetic acid, and the $4: 1$ ratio of the acids is essential for aroma formation and takes $12-24 \mathrm{~h}$ to form volatile compounds (Therdthai, 2014).

Stable sourdough from wheat or rye flour contains mainly heterofermentative LAB bacteria, and mainly Lactobacillus species. Lactobacillus spp. are able to ensure rapid sugar catabolism, which makes these species dominant in sourdough. In addition, the Lactobacillus spp. are persistent and in repeated backslopping they remain stable (PăcularuBurada et al., 2020).

In a previous study (Boreczek et al., 2020), after $48 \mathrm{~h}$, and $72 \mathrm{~h}$ of fermentation of wheat, spelt, and rye sourdough, the dominant populations of LAB were Lactobacillus spp., with isolated L. plantarum and L. brevis as dominant. The second largest isolate populations of LAB were Pediococcus sp. and Enterococcus sp. In that study, analysing the dominance of microorganisms in $24 \mathrm{~h}, 48 \mathrm{~h}$, and $72 \mathrm{~h}$ fermented sourdough, LAB spieces Weisella, Leuconostoc, and Lactococcus were isolated after $24 \mathrm{~h}$ fermentation, while after $48 \mathrm{~h}$ and $72 \mathrm{~h}$ fermentation they were no longer detected. Sourdough was similar at $48 \mathrm{~h}$ and $72 \mathrm{~h}$, suggesting that the maturity phase was approaching.

In a large-scale study (Gänzle and Zheng, 2019), it was shown that more than $95 \%$ of sourdoughs contain heterofermentative $\mathrm{LAB}$ or in combination with homofermentative Lactobacillus spp. In the 227 wheat and rye sourdough samples tested, the predominant ones were L. sanfranciscensis, L. plantaru, L. brevis, L. alimentarius, Leuconosctoc spp., and Weisella spp. The analysed sourdough samples were 
classified as type I sourdough and were collected mainly from Italy, France, Germany, and Belgium. Rye sourdough, collected mainly from Finland, Estonia, Denmark, and Germany, was classified as type II sourdough and dominant species were $L$. reuteri, $L$. pontis, $L$. panis, $L$ frumenti, $L$. delbrueckii, L .amylovorus, L. crispatus, L., and acidophilus. In type II sourdough, a higher fermentation temperature and longer time of fermentation is used, so other LAB bacteria adapt and dominate compared to type I sourdough. Also, they originated mostly from the Scandinavian and Baltic region, where scalds are prepared for sourdough production, which affects the fermentation temperature, and the amount of sugar for LAB fermentation.

The fermentation process is significantly influenced by the ambient temperature. To ensure stable bread quality and sensory value, determination and stabilisation of fermentation temperature is one of the main factors. A study conducted in Estonia compared rye sourdough stability in four bakeries in Estonian using controlled maintenance conditions $\left(32{ }^{\circ} \mathrm{C}\right.$ and $\left.42{ }^{\circ} \mathrm{C}\right)$ and changing conditions caused by different season $\left(19-30{ }^{\circ} \mathrm{C}\right)$. All sourdough samples were collected from medium-sized bakeries and monitored for 5-28 months. Analysing four different bakeries, each had a different LAB species as a dominant $-L$. amylovorus, $L$ frumenti, L. helveticus, L. pontis, and L. panis, when fermentation was held at a stable temperature, and L. sanfranciscensis, L. pontis, L. zymae, L. helveticus, when fermentation was held at ambient temperature. Ensuring uniform conditions (fermentation temperature), the stable dominance of these microorganism species occurred throughout the study, and the sourdough had a stable $\mathrm{pH}$ and cell density. When maintaining sourdough under changing conditions, insufficient $\mathrm{pH}$ was observed during winter months, which can be explained by low ambient temperatures. The stability of LAB species was also variable - the dominant LAB species changed with seasons and temperature. This study showed that the sourdough system can be stable for many months if constant environmental parameters are ensured (Viiard et al., 2016).

In the study on the spontaneous formation of rye sourdough from Latvia, the following lactic acid bacteria were identified: ? L. curvatus, L. delbrueckii, L. plantarum, L. alimentarius, Leuconostoc mesenteroides, and L. coryniformis. The sourdough was classified as type I and fermented for 48 hours (Kozlinskis, 2011).

During sourdough fermentation, LAB produces a variety of valuable metabolites. The amount of amino acids (tryptophan, methionine, lysine, glutamic acid, isoleucine, leucine, asparagine) is significantly higher in rye sourdough compared to unfermented rye doughs (Weckx et al., 2010; Koistinen et al., 2018). During fermentation, significant changes in metabolite levels are characteristic of rye sourdough compared to wheat sourdough. One of the main reasons for this is the conditions of the fermentation process wheat bread is characterised by lower acidity, and thus the fermentation time is usually shorter. In contrast, rye bread technology involves a higher temperature and longer fer- mentation time. Also, rye sourdough contains a wider range of compounds that are available for metabolites of microorganisms (Koistinen et al., 2018). Protein degradation and thus gluten reduction during fermentation also occurs, which has been studied extensively. During fermentation, the antioxidant capacity increases, and the amounts of antifungal and antibacterial compounds increase (diacetyl, acetate, reuterin, propionate fungicidal peptides) (Poutanen et al., 2009; Arendt and Moroni, 2013).

\section{SOURDOUGH - FOOD SAFETY AND SHELF-LIFE EXTENSION}

LAB produced metabolites have antifungal activity, which is especially important in the production of wholemeal flour products. Most moulds are found on the outside of the grain and this is why whole grain flour products are more susceptible to fungal infections. Many LAB strains have strong inhibitory properties against Penicillium citrinum, Aspergillus flavus, Aspergillus fumigatus, and Fusarium graminearum, which is often the reason for the reduction in bread shelf life (Sun et al., 2020).

One of the main reasons for the mould-reducing ability of sourdough is the formation of different metabolites and the rapid decrease in environmental $\mathrm{pH}$. Metabolites formed during fermentation are able to inhibit spoilage bacteria growth. These metabolites include organic acids (lactic acid, propionic acid, and acetic acid) and diacetyl, hydrogen peroxide, acetate, propionate, caproate, 3-hydroxy fatty acids, phenyllactate, cyclic dipeptides, reuterin, fungicidal peptides, and other secondary metabolites with antimicrobial properties, produced by LAB and yeast species. If sourdough is used, the acidity of the bread is higher, which prevents the formation of mould. Although some metabolites show good antifungal properties (for example, diacetyl), when a certain concentration in bread is reached, the aroma of bread deteriorates and the product is not attractive to the consumer (Gobbetti and Gänzle, 2013a; Siepmann et al., 2019). LAB fermentation produces acids such as lactic and acetic acid, cyclic dipeptides, and phenyllactic acid, which have antifungal properties, but often their total concentration in bread is too low to be effective against mould. One study (Debonne et al., 2020) examined the effect of chemical acidification of bread dough on the formation of two moulds - A. niger and P. paneum - was compared. In chemically acidified bread (acetic acid concentration 33 $\mathrm{mmol} \cdot \mathrm{kg}^{-1}$ dough) no development of $A$. niger was observed during 35 days storage at room temperature. In contrast, very high acetic acid concentrations $\left(>100 \mathrm{mmol} \cdot \mathrm{kg}^{-1}\right.$ dough) were required to prevent the growth of $P$. paneum. That study indicated that the effect of fermentation on mould formation cannot be generalised. The antifungal effect is considered to depend on the susceptibility of mould species to acetic acid and lactic acid.

Some of the LABs are able to release metabolites with stronger antifungal properties, but they are affected by the deterioration of sensor parameters. For example, propionic 
acid is produced by L. diolivorans and L. buchneri during co-fermentation. Propionic acid has antifungal properties, but it also affects the aroma and texture of bread. Quattrini et al. (2019) examined the interactions and minimum concentrations of different LAB fermentation metabolites and chemical preservatives needed to provide antifungal activity. To increase the acetate level in bread, fermentation with strains of $L$. hammesii was used, ?thereby reducing the amount of propionate required to obtain an extension of the shelf life of wheat bread. It was confirmed that it is possible to reduce the use of chemical preservatives and extend the shelf life if certain strains that can produce acetic acid are used.

Although there has been much research on the antifungal properties of sourdough, bakery mould is still one of the most pressing issues in industries that needs to be addressed to ensure a safe product and a long shelf life. Currently, the synergy of microorganisms and novel methods of bioconservation as well as combination of various inhibitory compounds are being studied. Particular attention is paid to the effect of LAB-produced metabolites EPSs on the shelf life, texture, and staling of bread.

\section{CHARACTERISTICS AND IMPORTANCE OF EPS ON THE TECHNOLOGICAL QUALITY AND PREBIOTIC PROPERTIES OF BREAD}

The use of EPS produced by microorganisms is increasingly used not only in the processing of dairy products, but also in the processing of cereals. For this reason, the fermentation process and the specific EPS-producing LAB strains and their application to sourdough systems have been extensively studied.

EPSs are microorganism-produced polysaccharides long-chain carbohydrate polymers that are very diverse and can have different sugar composition, branching, and linkage (Tsuda et al., 2019). EPS production is LAB straindependent, and not all LAB strains produce EPSs.

There are many ways to classify EPSs, but classification by monomer composition is the most commonly used. Based on composition, EPSs are divided into two groups: homopolysaccharides (HoPSs), which contain one type of monosaccharide, either glucose or fructose, formed from sucrose by glycosyltransferases, and heteropolysaccharides (HePS), which containing a combination of two to eight constituting monosaccharides (glucose, galactose, fructose and rhamnose). Both HoPS and HePS can be linear or branched in structure (Sanalibaba and Cakmak, 2016).

There are two ways LAB can produce EPS — intracellular synthesis (HePS) by glycosyltransferases using sugar nucleotides, or extracellular synthesis (HoPS) by glucansucrases or fructansucrase. Glucansucrase uses sucrose as substrate, while fructansucrase uses sucrose, raffinose, stachyose, verbascose as substrate (Gobbetti and Gänzle, 2013a).
EPS production is a complex process, briefly characterised by the following steps: assimilation of sugar (carbon substrate), synthesis of polysaccharides (synthesis of sugar nucleotides and repeating units), polymerisation of repeating units, and EPS transport outside the cell (Donot et al., 2012).

LAB strain screening indicates that only a few are capable of producing HePS and mostly HePS are formed in small amounts - up to $2 \mathrm{~g} \cdot \mathrm{l}^{-1}$. HoPS can be found in large amounts of up to $40 \mathrm{~g} \cdot \mathrm{l}^{-1}$ (Hermann et al., 2015).

HoPS classification is as follows: glucans can be sub-classified as dextrans, mutans, and reuterans, while fructans can be produced in two types - inulin and levan.

HePS, in turn, can have very different structures, and galactose, glucose, and rhamnose form their structure in most cases (Badel et al., 2011).

In-depth research of LAB and analysis of EPS production mechanisms indicate that not all LABs located in sourdough are capable of EPS production. However, in the sourdough microorganism ecosystem, at least one of the LAB strains is capable of producing EPS, and in all sourdough types EPS producers can be found (Kaditzky and Vogel, 2008). In order to further investigate the technological and prebiotic properties of EPSs, special emphasis is placed on the isolation of LAB strains, research on the mechanics of EPS production and optimisation possibilities to obtain the highest possible EPS yield in sourdough.

The amount of EPS produced during sourdough fermentation is sufficient to significantly affect the structure of the bread. EPSs improve the quality of the bread - the volume of the final product and crumb softness is increased, water absorption is increased, and the staling of bread is delayed, thus extending the shelf life (Lynch et al., 2018). The EPS (HoPS) produced by LAB acts as hydrocolloids in dough they have the ability to bind water, as well as they interact with other components (protein, starch), and influence structural networks and texture in various types of bread, including wholemeal bread (Lynch et al., 2018).

EPS is used as a safe thickener, emulsifier, and stabiliser in ice cream, cheese, bread, yogurt and meat products to improve the texture of product ( $\mathrm{Xu}$ et al., 2019).

Another technological improvement provided by the use of sourdough, which has received increased attention in recent years, is bread staling. EPS is mentioned as one of the potential anti-staling substances because it binds water leaving less water for migration.

The effect of sourdough on shelf life was studied by comparing EPS-forming (EPS +) and EPS non-forming (EPS-) LABs in sourdough. After 15 days of storage, the sample prepared with EPS+ sourdough showed higher moisture retention capacity (amount of sourdough in the dough 30 $\mathrm{g} \cdot 100 \mathrm{~g}^{-1}$ ), thus delaying the staling process (Torrieri et al., 2014). 
In order to stabilise the sourdough fermentation and obtain the optimal amount of EPSs, in addition to the specific choice of LAB strain, the conditions of how to optimise EPS production in sourdough fermentation have also been studied. There are many factors influencing yield of EPS during sourdough fermentation, the main ones being:

- strain properties (grow parameters, expression of enzymes - glucansucrase/fructansuctrase, formation of other metabolites);

- enzyme properties ( $\mathrm{pH}$, temperature optimum, polymer properties, ratio of hydrolysis to transferase);

- substrate-flour (concentration of acceptor carbohydrates and release during fermentation, presence of structure forming polymers); and

- process conditions (time, temperature, sucrose amount, dough yield) (Kaditzky and Vogel, 2008; Rühmkorf et al., 2012; Gobbetti and Gänzle, 2013a).

Growth conditions and LAB strain choice are considered in depth when optimising the production to obtain a substantial EPS yield. It is important to consider the synergy of all parameters in general, because they change not only EPS yield, but also dough and bread properties in general.

During the growth phase of the microorganisms, the amount of EPS formation is greater during the exponential phase and production in the stationary growth phase is not observed (Sanalibaba and Cakmak, 2016).

A long fermentation time can affect the total amount of metabolites, including the formation of EPSs. Acetic acid bacterial strains and different types of flour (wheat, spelt, rye) were compared in production of EPS in a 48-hour fermentation period (Hermann et al., 2015). The calculated EPS maximum for fermentation with $K$. baliensis was around $35 \mathrm{~h}$ of fermentation for all flour types, a slight degradation was observed thereafter, while the maximum with $N$. chiangmaiensis was $48 \mathrm{~h}$ for whole wheat and rye dough. The study also confirmed that a higher added sucrose dose provided a higher EPS yield. As the fermentation time can significantly affect the dynamics of EPS formation, this factor must also be taken into account when optimising to improve the technological processes of rye bread.

EPS producing strains L. animalis, L. cervatus, and $L$. reuteri were compared using different types of gluten free flours, dough yields, cell counts and sucrose concentrations to optimise in situ EPS production (Rühmkorf et al., 2012). The results showed that flour type and strain significantly affected the formation of EPSs. For example, L. animalis produced the most EPS in buckwheat core sourdough $\left(14.74 \mathrm{~g} \cdot \mathrm{kg}^{-1}\right)$ and L. reuteri produced most EPS in quinoa sourdough $\left(20.63 \mathrm{~g} \cdot \mathrm{kg}^{-1}\right)$. Also, a higher amount of sucrose resulted in more EPS production, as well as more acetate and mannitol and less lactate and ethanol. It should be noted that high acetate concentrations may adversely affect the taste of the final product. Another observation was correlation of EPS production with the number of cells at the be- ginning of fermentation $(r=0.98)$, but increase of cell count during fermentation after $24 \mathrm{~h}$ did not significantly affect the dynamics of EPS formation. The optimal fermentation time was $24 \mathrm{~h}$. After $24 \mathrm{~h}$, EPS production did not increase, as sucrose in the dough was completely consumed by that time.

L. reuteri is an EPS-producing strain found in long-term sourdough fermentation (type II), where a higher fermentation temperature than for type I sourdough is usually used. To optimise EPS production with strain L. reuteri, various factors influencing fermentation such as dough yield, $\mathrm{pH}$, sucrose concentration and different substrates (wheat, rye flour and rye bran) were compared. A higher dough yield was found to increase EPS production as well as the amount of other metabolites, such as lactate. The lower EPS yield in harder doughs is due to lower water activity and limited sucrose and enzyme diffusion. The fermentation time affects the formation of EPSs, but after consuming sucrose, prolonging the fermentation time will not increase EPS production (Rühmkorf et al., 2012). Extending the fermentation time from $24 \mathrm{~h}$ to $48 \mathrm{~h}$ was found to result in a higher amount of organic acids, but EPS production did not increase proportionally (Kaditzky and Vogel, 2008).

A similar optimisation study using L. rhamnosus also confirmed that the highest EPS concentration is reached after $24 \mathrm{~h}$ of fermentation, but the fermentation temperature significantly affected the optimal fermentation time (OleksySobczak et al., 2020). It was also reported that a higher concentration of EPS can be achieved with greater biomass of bacteria.

Optimisation of EPS production is a current issue for scientists, as unambiguous cultivation conditions are still not implemented and their study is ongoing. It is known that the fermentation time and environmental factors significantly affect EPS synthesis, and therefore, in-depth strain-substrate optimisation studies are essential to achieve truly sustainable and significant EPS production in the sourdough product, resulting in both technological and functional properties.

One of the main factors affecting EPS synthesis is saccharide composition in the culture medium (Oleksy-Sobczak et al., 2020). Starch consists of amylopectin and amylose, which are $\mathrm{x}$-D-glucose polymers. The hydrolytic processes of starch have been extensively studied, especially in the endosperm of germinating grains. The starch in grain endosperm is a storage starch and alpha-amylase plays a key role in its degradation, as alpha-amylase is the most common amylolytic enzyme that can breakdown starch granules. The enzyme hydrolyses amylose and amylopectin from starch to produce mixture of dextrins, maltose and oligosaccharides. Beta-amylase hydrolyses amylose and amylopectin and produce maltose (Savkina et al., 2020).

During traditional Latvian rye bread preparation, scald is made to obtain more fermentable sugars with starch degradation by alpha and beta amylases. 
Analysing studies using specific rye flour or rye bran sourdough, the following LAB bacteria and their produced EPSs are mainly mentioned:

L. reuteri, producing glucan (Kaditzky and Vogel, 2008);

L. sanfranciscensis, producing fructan and mannitol (Korakli et al., 2002);

L. plantarum, producing glucan, fructan, levan;

L. citreum, producing glucan, levan;

L. mesenteroides, producing dextran (Lacaze et al., 2007);

L. graminis, producing glucan (Ispirli et al., 2018);

W. cibaria, producing glucan (Kajala et al., 2016) and dextran (Baruah et al., 2017);

W. confuse, producing dextran (Kajala et al., 2016).

Most of the EPS-producing bacteria are mentioned in studies on the microflora of rye flour sourdough in the Baltic region - L. plantarum (Bessmeltseva et al., 2014; Kozlinskis, 2011), L. sanfranciscensis (Viiard et al., 2016), L. mesenteroides, W. cibaria (Kozlinskis, 2011), and W. confuse (Bessmeltseva et al., 2014).

It should be noted that wheat flour has been used mainly in the research, and there is little information about rye flour, especially wholemeal rye flour, which is often used in Latvian traditional rye bread. When using wholemeal rye flour, the dynamics of EPS production can change, and the fermentation time can be extended.

The formation of other metabolites should also be taken into account when adjusting the optimal conditions for EPS production during sourdough fermentation. By increasing the amount of sucrose and promoting the formation of EPS, the acidity in the sourdough system increases, with higher amounts of organic acids (lactate and acetate) produced (Kaditzky and Vogel, 2008). Acidity can significantly affect the rheological and technological properties of the dough, and even more importantly, the consumer's liking of the final product.

The current lifestyle raises the importance of not only the sensory properties of the product, but especially the nutritional and functional quality. When developing new bakery products or optimising technological solutions in the production of existing products, not only are technological properties taken into account, but special attention is paid to functional properties, i.e. how products can bring positive benefits to human health and well-being. As consumer awareness increases, the demand for such products grows.

EPSs produced by LAB have recently received increased attention due to health benefits to the consumers. More and more studies have shown that EPS produced by LAB can improve the growth of probiotics (bifidobacteria and lactobacteria) working as prebiotics in the human body, thus improving immune function (Farias et al., 2019). Of particular interest about possible prebiotic functions are EPSs produced by LAB (Wang et al., 2020).

Despite the technological application, in recent years, it is the effect on immune regulation that has attracted the interest of scientists. In vitro and in vivo models have been used to evaluate the immune effect of EPSs. The main focus is on prebiotic activity and immune stimulating activities, inhibition of enteropathogenesis, cholesterol lowering, antitumour, antioxidant, and antibacterial activities. EPS can lower cholesterol levels and thus prevent cardiovascular diseases, and they are able to form complexes with free radicals (Păcularu-Burada et al., 2020).

It should be noted that sourdough is a complex system and not only does EPS production increase during fermentation, but also the bioavailability of minerals improves (because proteins and phytates are degraded), and use of LAB strains results in production of antioxidants (Gobbetti and Gänzle, 2013b) as well as postbiotic compounds- short chain fatty acids (SCFA), for example, propionate, butyrate (PăcularuBurada et al., 2020).

\section{CONCLUSION}

In sourdough fermentation it is possible to produce enough EPS to significantly improve bread quality and reduce the need to add hydrocolloids and preservatives. Choosing EPS producing LAB strains can provide a high quality, safe product and clean label. By choosing the LAB strain and providing optimal conditions for the formation of a specific dominant $\mathrm{LAB}$, and by choosing the appropriate raw material (flour), as well as fermentation conditions (time, temperature) and dough yield, the optimal conditions for the formation of EPS can be ensured. LAB-produced EPSs have GRAS (generally recognises as safe) status, are able to withstand low $\mathrm{pH}$ (during fermentation), resistant to high temperature (during baking) (Chavan and Chavan, 2011), and therefore they are acceptable in foods as a prebiotic ingredient.

In developing and maintaining fermented rye bread traditions Latvian and Baltic States, it is important to identify specific technology values. In turn, when creating new fermented rye products, it is important to take into account not only technological but also nutritional aspects. Although much of the research has been done using wheat and other cereal flour, there are also specific studies on rye sourdough and EPS formed during fermentation. Some of the EPS-producing LABs mentioned in the studies have been identified in both Latvian and Baltic rye sourdough, which creates a basis for recognition of the functional properties of rye bread. The traditional long fermentation time as well as scald use can affect the amount of sugars to be fermented and the amount of substrate for EPS production. More research specifically on rye sourdough fermentation and metabolite formation is needed. 


\section{REFERENCES}

Arendt, E. K., Moroni, A. V. (2013). Sourdough and gluten-free products. In: Gobbetti, M., Gänzle, M. (eds.). Handbook on Sourdough Biotechnology. Springer Science, Business Media, New York, pp. 245-264.

Badel, S., Bernardi, T., Michaud, P. (2011). New perspectives for lactobacilli exopolysaccharides. Biotechnol. Adv., 29 (1), 54-66.

Baruah, R., Maina, N. H., Katina, K., Juvonen, R., Goyal, A. (2017). Functional food applications of dextran from weissella cibaria RBA12 from pummelo (Citrus maxima). Int. J. Food Microbiol., 242, 124-131.

Bessmeltseva, M., Viiard, E., Simm, J., Paalme, T., Sarand, I. (2014). Evolution of bacterial consortia in spontaneously started rye sourdoughs during two months of daily propagation. PLoS ONE, 9 (4), 10-11.

Boreczek, J., Litwinek, D., Izak, D., Buksa, K., Gawor, J., Gromadka, R., Karol, J., Kowalczyk, M. (2020). Bacterial community dynamics in spontaneous sourdoughs made from wheat, spelt, and rye wholemeal flour. Microbiol. Open, 9 (4), 1-13.

Chavan, R. S., Chavan, S. R. (2011). Sourdough technology - a traditional way for wholesome foods: A review. Comprehens. Rev. Food Sci. Food Safety, 10 (3), 169-182.

Corsetti, A. (2013). Technology and biodiversity of sourdough yeasts and lactic acid bacteria. In: Gobbetti, M., Gänzle, M. (eds.). Handbook on Sourdough Biotechnology. Springer Science, Business Media, New York, pp. 85-104.

De Vuyst, L., Van Kerrebroeck, S., Leroy, F. (2017). Microbial ecology and process technology of sourdough fermentation. Adv. Appl. Microbiol., 100, 49-160.

Debonne, E., Maene, P., Vermeulen, A., Van Bockstaele, F., Depredomme, L., Vermeir, P., Eechout, M., Devlieghere, F. (2020). Validation of in-vitro antifungal activity of the fermentation quotient on bread spoilage moulds through growth/no-growth modelling and bread baking trials. Lwt - Food Sci. Technol., 117, 108636.

Donot, F., Fontana, A., Baccou, J. C., Schorr-Galindo, S. (2012). Microbial exopolysaccharides: Main examples of synthesis, excretion, genetics and extraction. Carbohydrate Polymers, 87 (2), 951-962.

Farias, D. de P., de Araújo, F. F., Neri-Numa, I. A., Pastore, G. M. (2019). Prebiotics: Trends in food, health and technological applications. Trends Food Sci. Technol., 93, 23-35.

Gobbetti, M., Gänzle, M. (2013a). Physiology and biochemistry of lactic acid bacteria. In: Gobbetti, M., Gänzle, M. (eds.). Handbook on Sourdough Biotechnology. Springer Science, Business Media, New York, pp. 279-285

Gobbetti, M., Gänzle, M. (2013b). Perspectives. In: Gobbetti, M., Gänzle, M. (eds.). Handbook on Sourdough Biotechnology. Springer Science, Business Media, New York, pp. 279-285.

Gänzle, M. G., Zheng, J. (2019). Lifestyles of sourdough lactobacilli - do they matter for microbial ecology and bread quality? Int. J. Food Microbiol., 302, 15-23.

Hermann, M., Petermeier, H., Vogel, R. F. (2015). Development of novel sourdoughs with in situ formed exopolysaccharides from acetic acid bacteria. Eur. Food Res. Technol., 241 (2), 185-197.

Huys, G., Daniel, H. M., Vuyst, L. D (2013). Taxonomy and biodiversity of sourdough yeasts and lactic acid bacteria. In: Gobbetti, M., Gänzle, M. (eds.). Handbook on Sourdough Biotechnology. Springer Science, Business Media, New York, pp. 105-154.

Ispirli, H., Demirbaş, F., Yüzer, M. O., Dertli, E. (2018). Identification of lactic acid bacteria from spontaneous rye sourdough and determination of their functional characteristics. Food Biotechnol., 32 (3), 222-235.

Kaditzky, S., Vogel, R. F. (2008). Optimization of exopolysaccharide yields in sourdoughs fermented by lactobacilli. Eur. Food Res. Technol., 228 (2), 291-299.
Kajala, I., Mäkelä, J., Coda, R., Shukla, S., Shi, Q., Maina, N. H., Juvonen, M., Ekholm, P., Goyal, A., Tenkanen, M., Katina, K. (2016). Rye bran as fermentation matrix boosts in situ dextran production by Weissella confusa compared to wheat bran. Appl. Microbiol. Biotechnol., 100 (8), 3499-3510.

Koistinen, V. M., Mattila, O., Katina, K., Poutanen, K., Aura, A. M., Hanhineva, K. (2018). Metabolic profiling of sourdough fermented wheat and rye bread. Sci. Rep., 8 (1), 1-11.

Korakli, M., Gänzle, M. G., Vogel, R. F. (2002). Metabolism by bifidobacteria and lactic acid bacteria of polysaccharides from wheat and rye, and exopolysaccharides produced by Lactobacillus sanfranciscensis. J. Appl. Microbiol., 92 (5), 958-965.

Kozlinskis, E. (2011). Development of microbial populations in spontaneous rye bread sourdoughs. Summary of Doctoral thesis. Latvia University of Agriculture, Jelgava, Latvia. 66 pp.

https://1lufb.1lu.1v/dissertation-summary/food-microbiology/ Emils-Kozlinskis_promocijas_darba_kopsavilkums_2011_LLU_PTF.pdf (accessed 10 October 2020).

Lacaze, G., Wick, M., Cappelle, S. (2007). Emerging fermentation technologies: Development of novel sourdoughs. Food Microbiol., 24 (2), $155-160$.

Lynch, K. M., Coffey, A., Arendt, E. K. (2018). Exopolysaccharide producing lactic acid bacteria: Their techno-functional role and potential application in gluten-free bread products. Food Res. Int., 110, 52-61.

Oleksy-Sobczak, M., Klewicka, E., Piekarska-Radzik, L. (2020). Exopolysaccharides production by Lactobacillus rhamnosus strains: Optimization of synthesis and extraction conditions. LWT-Food Sci. Technol., 122, 109055 .

Păcularu-Burada, B., Georgescu, L. A., Bahrim, G. E. (2020). Current approaches in sourdough production with valuable characteristics for technological and functional applications. Ann. Univ. Dunarea de Jos of Galati, Fascicle VI Food Technol., 44 (1), 132-148.

Poutanen, K., Flander, L., Katina, K. (2009). Sourdough and cereal fermentation in a nutritional perspective. Food Microbiol., 26 (7), 693-699.

Quattrini, M., Liang, N., Fortina, M. G., Xiang, S., Curtis, J. M., Gänzle, M. (2019). Exploiting synergies of sourdough and antifungal organic acids to delay fungal spoilage of bread. Int. J. Food Microbiol., 302, 8-14.

Rühmkorf, C., Jungkunz, S., Wagner, M., Vogel, R. F. (2012). Optimization of homoexopolysaccharide formation by lactobacilli in gluten-free sourdoughs. Food Microbiol., 32 (2), 286-294.

Sanalibaba, P., Cakmak, G. A. (2016). Exopolysaccharides production by lactic acid bacteria. Appl. Microbiol., 2 (2), 1000115.

Savkina, O., Kuznetsova, L., Burykina, M., Kostyuchenko, M., Parakhina, O. (2020). The influence of the flour amylolytic enzymes activity, dosage of ingredients and bread making method on the sugar content and the bread quality. Agron. Res., 18 (Special Issue 3), 1873-1887.

Siepmann, F. B., Sousa de Almeida, B., Waszczynskyj, N., Spier, M. R. (2019). Influence of temperature and of starter culture on biochemica characteristics and the aromatic compounds evolution on type II sourdough and wheat bread. LWT - Food Sci. Technol., 108, 199-206.

Sun, L., Li, X., Zhang, Y., Yang, W., Ma, G., Ma, N., Hu, Q., Pei, F. (2020). A novel lactic acid bacterium for improving the quality and shelf life of whole wheat bread. Food Control, 109, 106914.

Therdthai, N. (2014). Fermentation. In: Zhou, W. (Ed.). Bakery Products Science and Technology. Second Edition. John Wiley \& Sons, pp. 326-334.

Tieking, M., Gänzle, M. G. (2005). Exopolysaccharides from cereal-associated lactobacilli. Trends Food Sci. Technol., 16 (1-3), 79-84.

Torrieri, E., Pepe, O., Ventorino, V., Masi, P., Cavella, S. (2014). Effect of sourdough at different concentrations on quality and shelf life of bread. LWT - Food Sci. Technol., 56 (2), 508-516. 
Tsafrakidou, P., Michaelidou, A. M., Biliaderis, C. G. (2020). Fermented cereal-based products: Nutritional aspects, possible impact on gut microbiota and health implications. Foods, 9 (6), 734.

Tsuda, H., Okuda, S., Haraguchi, T., Kodama, K. (2019). Influence of exopolysaccharide on the growth of lactic acid bacteria. Italian J. Food Sci., 31 (2), 233-242.

Viiard, E., Bessmeltseva, M., Simm, J., Talve, T., Aaspõllu, A., Paalme, T., Sarand, I. (2016). Diversity and stability of lactic acid bacteria in rye sourdoughs of four bakeries with different propagation parameters. PLOS ONE, 11 (2), 5-6.

Waldherr, F., Vogel, R. F. (2009). Commercial exploitation of homoexopolysaccharides in non-dairy food. In: Ullrich, M. (Ed.). Bacterial Polysaccharides: Current Innovations and Future Trends. Caister Academic Press, Poole, pp. 313-329.

Received 22 March 2021

Accepted in the final form 12 January 2022
Wang, Y., Trani, A., Knaapila, A., Hietala, S., Coda, R., Katina, K., Maina, N. H. (2020). The effect of in situ produced dextran on flavour and texture perception of wholegrain sorghum bread. Food Hydrocolloids, 106, 105913.

Weckx, S., Van der Meulen, R., Maes, D., Scheirlinck, I., Huys, G., Vandamme, P., De Vuyst, L. (2010). Lactic acid bacteria community dynamics and metabolite production of rye sourdough fermentations share characteristics of wheat and spelt sourdough fermentations. Food Microbiol., 27 (8), 1000-1008.

Xu, Y., Cui, Y., Yue, F., Liu, L., Shan, Y., Liu, B., Zhou, Y., Lü, X. (2019). Exopolysaccharides produced by lactic acid bacteria and bifidobacteria: Structures, physiochemical functions and applications in the food industry. Food Hydrocolloids, 94, 475-499.

\section{ILGA FERMENTĀCIJAS LAIKA IETEKME UZ RUDZU MAIZES TEHNOLOG̣ISKAJĀM UN PREBIOTISKAJĀM ĪPAŠĪBĀM}

Raudzētas rudzu rupjmaizes tehnolog̣ija ir tradīciju vērtība Latvijā, šo rupjmaizi gatavo, izmantojot plaucējumu un ieraugu. Mikroorganismiem ir būtiska loma ierauga un plaucējuma fermentācijas procesā, galvenokārt to nodrošina tieši pienskābās baktērijas. Parasti ieraugs satur 2-5 pienskābo baktēriju sugas. Atkarībā no maizes ceptuves kopējais fermentācijas laiks var būt no 6 līdz 48 stundām. Vieni no metabolītiem, kas tiek producēti plaucējuma fermentācijas laikā, ir eksopolisaharīdi (EPS). Ir konstatēts, ka apmēram $20 \%$ no pienskābajām baktērijām ieraugos spēj producēt EPS, galvenokārt tie ir fruktāni un glikāni. Pienskābes baktēriju producētie EPS spēj saistīt ūdeni, tādā veidā uzlabojot maizes kvalitāti — palielinās maizes apjoms, palēninās maizes cietēšana, tādā veidā pagarinās uzglabāšanas laiks. Daudzi pētījumi ir parādījuši, ka pienskābo baktēriju producētie EPS var uzlabot probiotiku augšanu cilvēka ḳermenī, tādā veidā uzlabojot imūno funkciju. Īpaša interese ir par iespējamajām prebiotiskajām īpašībām, kas piemīt pienskābes baktēriju producētiem EPS. Tradicionālais rudzu maizes tehnoloğiskais process, kas ietver ilgu rudzu maizes plaucējuma fermentācijas laiku, var uzlabot maizes struktūru, kvalitāti un uzglabāšanas laiku, kā arī funkcionāli ieteikmēt cilvēka imūno sistēmu. 